\title{
A CASE REPORT OF CLOACOGENIC CARCINOMA OF ANO-RECTUM
}

\author{
M. Madan ${ }^{1}$, K. Nischal'2, Sharan Basavaraj. C. J3.
}

\section{HOW TO CITE THIS ARTICLE:}

M. Madan, K. Nischal, Sharan Basavaraj. C. J. "A case report of cloacogenic carcinoma of ano-rectum". Journal of Evolution of Medical and Dental Sciences 2013; Vol2, Issue 28, July 15; Page: 5206-5208

ABSTRACT: Cloacogenic carcinoma is a rare tumor of the ano-rectal region originating from a persistent remnant of the cloacal membrane of the embryo. The tumor accounts for $2-3 \%$ of anorectal carcinomas. Abdominoperineal resection is the treatment of choice with a five year survival of $50 \%$.

KEYWORDS: Cloacogenic, rectum.

INTRODUCTION: Most common anorectal cancer is Adenocarcinoma. Squamous cell (nonkeratinizing squamous cell or basaloid) carcinoma of the anorectum accounts for 3 to $5 \%$ of distal large-bowel cancers. Basal cell carcinoma, Bowen's disease (intradermal carcinoma), extramammary Paget's disease, malignant melanoma are less common.

REVIEW OF LITERATURE: Hermann \& Defosses in 1880 described the embryological, histological \& anatomical characteristics of anorectal region. Bacon in 1932 has described column of Morgagni as persistent remnant of cloacal membrane. Different histological varieties of carcinoma of rectum has been described as cloacogenic, transitional, basaloid, small cell, undifferentiated, mucoepidermoid, adenocarcinoma, adenoacanthoma \& cylindroma.

Cloacogenic carcinoma of Anorectal region is seen more in the region below or at the pectinate line, they must be differentiated from inflammatory lesions. Any nodule, ulcer or lesion in the anorectal region must be biopsied and looked for histological variants. The most common variant of cloacogenic carcinoma is transitional variant with transitional differentiation.

Many modalities of treatment have been suggested like radiotherapy and surgery. A wide abdominoperineal resection is the best choice for primary lesion followed by radiotherapy for recurrence.

CASE REPORT: A 60 yrs old female presented to us with complaints of bleeding per rectum since one year associated with pain and loose stools.

- Per Rectal Examination:

Circumferential growth palpable in the posterior wall. Anterior wall partially free. Upper border of the growth could be reached.

- Proctoscopy:

Irregular mucosa with circumferential growth was visualised, with discharge of mucus and blood

- Colonoscopy(301898):

- Ulcero-proliferative growth involving the posterolateral wall of rectum starting from anal verge extending $10 \mathrm{~cm}$ distally.(FIGURE 1) 


\section{CASE REPORT}

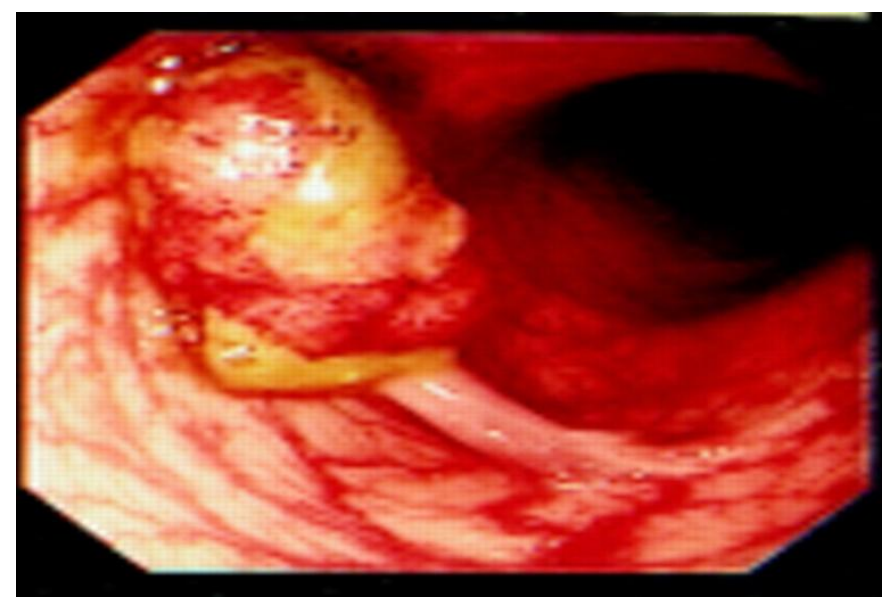

\section{FIGURE 1:}

Colonoscopic biopsy was done and sent for histopathological examination.

- C T Abdomen Pelvis:

Thickened ano rectal wall with likely extension into the serosa

- USG Abdomen :

No significant abnormality, no evidence of metastasis in the liver, no ascites

\section{HISTOPATHOLOGY:}

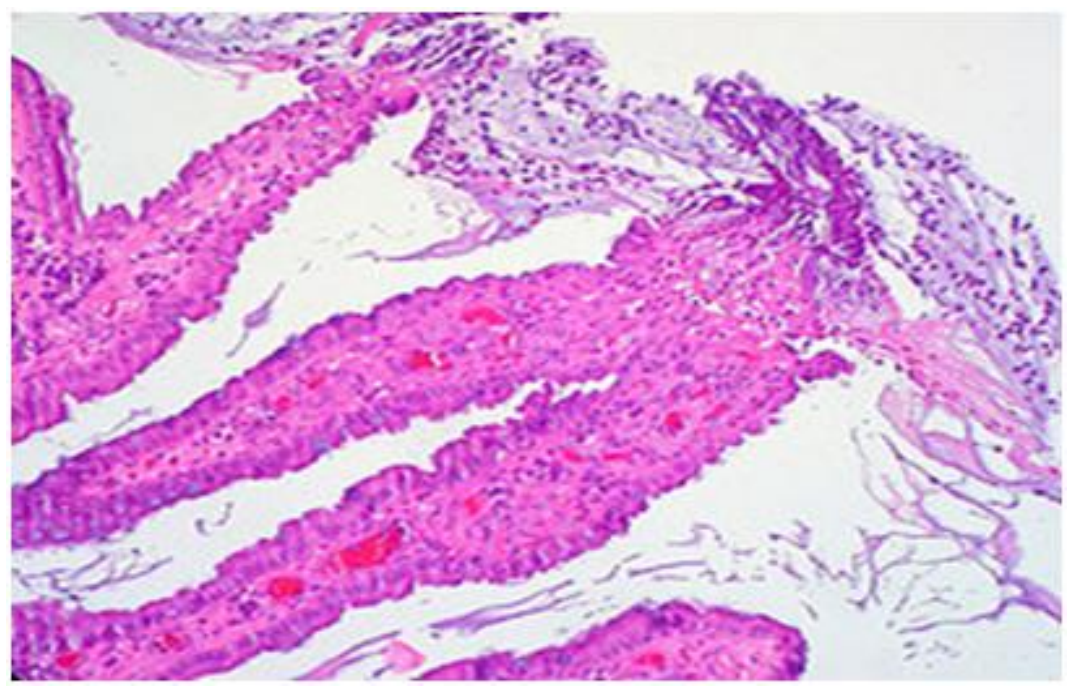

FIGURE 2: Poorly Differentiated Carcinoma- Transitional Cloacogenic Carcinoma

\section{TREATMENT:}

- CONCURRENT CHEMO-RADIATION WAS DONE AND PATIENT RESPONDED WELL WITH REGRESSION OF SIZE IN THE GROWTH AND SYMPTOM-FREE TILL DATE.

CONCLUSION: Cloacogenic carcinoma is a rare tumor of the anorectal region originating from a persistent remnant of the cloacal membrane of the embryo. The tumor accounts for $2-3 \%$ of anorectal carcinomas and occurs more than twice as often in women. Most tumors present as fungating or ulcerating lesions, but the tumor may arise in anal ducts and present as a submucosal mass. Wide abdominoperineal resection is the treatment of choice with a five year survival of $50 \%$. 
But newer literature says radiation is the treatment of choice and we report our good experience with it.

\section{REFERENCES:}

1. Sink J D, Kramer. S.A, Copeland D D. Cloacogenic Carcinoma Rectum. Ann surg, 1978 July, 188(1), 53-57.

2. Serota Alweil M, Williams RA, Wollman JS, Wilson SE. Cloacogenic Carcinoma anal canal and its Management. Arch surg, 1981 April, 116(4), 456-9.

3. Kosugi M, Nakashima. H, Annen Y. "Cloacogenic Carcinoma with reference to Malignant Tumors of Anal Canal”. Japanese journal of Clinical Medicine, dec1994, suppl 6, pg 781-3.

\section{AUTHORS:}

1. M. Madan

2. K. Nischal

3. Sharan Basavaraj. C.J.

\section{PARTICULARS OF CONTRIBUTORS:}

1. Professor \& HOD, Department of General Surgery, SDUMC.

2. Associate Professor, Department of General Surgery, SDUMC.

3. Post Graduate, Department of General Surgery, SDUMC.

\section{NAME ADRRESS EMAIL ID OF THE} CORRESPONDING AUTHOR:

Dr. K. Nischal,

Dept of General Surgery,

Sri Devaraja Urs Medical College,

Tamaka, Kolar.

Email-knischal697@gmail.com

Date of Submission: 28/06/2013.

Date of Peer Review: 28/06/2013.

Date of Acceptance: 10/07/2013.

Date of Publishing: 15/07/2013 